\title{
O NÃO-BRANCO, O SERTÃO E O PENSAMENTO
}

SOCIAL BRASILEIRO

René Marc da Costa Silva*

\section{Introdução}

Existe, desde pelo menos meados do século XIX, uma bem estruturada e persistente matriz dualista em importantes interpretações da sociedade brasileira. No sentido trazido por estas interpretações, "sertão e litoral representam os contrastes de uma sociedade vista como o principal problema a ser investigado, e que foi objeto de diferentes tentativas de interpretação. A idéia de um país moderno no litoral, em contraposição a um país refratário à modernização, no interior, quase sempre conviveu com concepção oposta, que acentuava a autenticidade do sertão em contraste com o parasitismo e a superficialidade litorâneos. [...] A presença do tema pode ser associada [...] à forma como os intelectuais percebem os caminhos da modernidade na sociedade brasileira, particularmente no que se refere às distâncias sociais e culturais"

Mais do que isso, essa relação atraso/modernidade, a partir do dualismo sertãolitoral, estava orientada para analisar a viabilidade da construção de uma civilização brasileira

\footnotetext{
${ }^{*}$ Graduado em Antropologia e História pela Universidade de Brasília - UNB, Mestre e Doutor em História também pela UnB, professor Substituto na UnB, Professor na Upis, Professor no IESB e Professor no UniCeub. E-mail: renecostasilva@gmail.com.

${ }^{1}$ LIMA, Nísia Trindade. Um sertão chamado Brasil - Intelectuais, sertanejos e imaginação social, Rio de Janeiro, Tese apresentada ao Instituto Universitário de Pesquisas do Rio de Janeiro, 1997, p.1 e 2.

PRISMAS: Dir., Pol.Pub. e Mundial., Brasília, v.3, n, 2, p. 427-454, jul/dez.2006 
integrada $^{2 .}$ Tal se apresenta como um dos eixos centrais de representação do processo de nation-building, e o homem do interior foi, no centro dessas representações, uma das categorias mais importantes abordadas ${ }^{3,}$ analisadas e interpretadas pelo pensamento social, presentes nos textos dos intelectuais de 1850 até, pelo menos, 19644. Em torno destas populações, compreendidas a partir do preestabelecimento de uma determinada hierarquia de raças, de sua inserção em um espaço geo-simbólico identificado como sertão, articularam-se portanto diversos valores e significados, em tudo conformadores de uma história mítica de uma comunidade imaginada chamada Brasil.

Em resumo, a partir de meados do século XIX, as possibilidades de construção de uma civilização brasileira foram entendidas pelo pensamento social brasileiro, cada vez mais, como estando ligadas ou dependentes da organização de um Estado capaz de integrar política, econômica, territorial e socialmente (vale dizer, racialmente) o espaço nacional. Neste sentido, como o povo brasileiro (recorrentemente entendido pelo viés ou pela ótica racial) foi

\footnotetext{
${ }^{2}$ Sidney Pimentel denomina "impulso domesticador" as várias iniciativas (mais freqüentes a partir da Primeira República) de integrar vastas regiões interiores do país ao projeto modernizador do Estado nacional. O autor assinala que, "desde o descobrimento, o campo semântico do signo-sertão encontrou-se sempre demarcado por conteúdos que o aproximavam da noção de selvageria. As idéias recorrentes na maioria dos autores que recobrem esse período são as da vastidão, do espaço vazio ou habitado pelo outro, do isolamento, da natureza indomada, do contato perigoso, da impossibilidade do convívio pacífico entre o sertão e seu antípoda, que às vezes é a nação, mas que pode também ser a cidade, a civilização, o litoral, uma região menos atrasada". Entretanto, "não obstante a idéia do sertão como espaço da selvageria nunca tenha de fato sido substituída", Pimentel assegura que "houve um momento em que a esta veio agregar-se uma outra noção, marcada por aquilo a que chamei impulso domesticador", PIMENTEL. Sidney Valadares.. O chão é o limite: a festa do peão de boiadeiro e a domesticação do sertão. Goiânia: UFG, 1997, p. 20; Presentes, como vimos, em Sidney Pimentel, o tema e as reflexões sobre as sucessivas iniciativas integradoras podem ser encontradas também em outros autores como Lúcia Lippi Oliveira (1990), Nísia Trindade Lima (1997) e residualmente em Lilia Moritz Schwarcz (1993).

${ }^{3}$ A questão racial, nesse âmbito, apresentou-se, em quase todos os projetos de nation-building, como uma categoria recorrente e central para se discutir as possibilidades de civilização de toda a nação brasileira. Qual o papel do povo (das raças), seu lugar e suas tarefas diferenciadas no processo de modernização e evolução do processo civiliza(na)cional brasileiro e também qual o papel desempenhado por elas no atraso do país, eventualmente identificado por estes intelectuais. A ruptura com estas matrizes de pensamento racial ou biologizante, como nos faz ver Lippi Oliveira, matrizes estas estabelecidas no interior do pensamento social romântico da segunda metade do século XIX, nunca se verificou de forma completa no âmbito do moderno pensamento social brasileiro, inaugurado na Primeira República. Como diz a autora: "as visões de mundo de Renan e Taine foram fontes de inspiração para parcela considerável da intelectualidade literária do Brasil da Primeira República. O determinismo preso às leis inexoráveis da natureza física e biológica marca o pensamento moderno brasileiro, ou seja, aquele que rompeu com o nosso passado romântico do século XIX". OLIVEIRA, Lúcia Lippi. A questão nacional na primeira república. São Paulo, Brasiliense, 1990, p. 73.

4 "A construção de argumentos sociológicos é relacionada ao processo de nation-building, com suas dimensões de integração territorial e dos estratos sociais. [...] No caso brasileiro, a representação do processo de nationbuilding apresentou como um dos eixos centrais o dualismo entre o litoral e o sertão presente em toda uma tradição de estudos que teve como objeto o homem das regiões interioranas quer este fosse identificado no sertanejo, no caboclo ou no caipira. O homem do interior foi um dos objetos privilegiados nos textos de cunho sociológico produzidos na segunda metade do século XIX, nas três primeiras décadas do século XX e na fase de institucionalização universitária das ciências sociais, que pode ser aproximadamente demarcada entre os anos de 1933 a 1964. Em suma, durante o período em que o Brasil foi considerado 'o grande enigma a ser decifrado em seus aspectos sócio-antropológicos, étnicos e culturais’”. LIMA, Nísia Trindade. Op. Cit., p. V, 2 e 3 .
} 
equacionado nos discursos ou intervenções de variados intelectuais que estabeleceram o sertão como o espaço geográfico-social mais autêntico para a definição da nacionalidade? Isto é, como especificamente as populações não-brancas ${ }^{5}$, elementos constitutivos fundamentais presentes nos espaços interiores do país, foram pensadas pela intelectualidade inventora da nação brasileira? Quais as contribuições possíveis imaginadas para estas no processo de construção ou de evolução de uma nação e de uma civilização brasileira?

$\mathrm{Na}$ maioria dos discursos do pensamento social brasileiro sobre os sertões e a importância do contingente populacional não-branco na sua formação, sobretudo no discurso histórico, são constantes duas atitudes intelectuais básicas: a primeira insiste na insignificância numérica destas populações não-brancas (principalmente do negro) e na sua precária influência para a composição racial que formou o que se considera como o típico homem sertanejo; a segunda enfatiza a significativa participação do sangue destas populações (principalmente o indígena, nas suas misturas com o branco) na base formativa do elemento humano considerado o mais legítimo representante destas regiões do país.

Tanto num caso como no outro, a determinação racial é considerada o elemento que introduz este enorme contingente populacional no cenário dos acontecimentos passados mais importantes para a formação histórica do sertão, e a partir deste, para a formação identitária do país (os elementos ou aspectos definidores do caráter ou do ethos nacional e alguns dos seus valores mais fundamentais). Nas duas posições, e nas várias escalas e gradações intermediárias entre elas, a porta de entrada para a história desta parcela étnica do povo brasileiro é sempre a biológica.

Estes discursos, ao trazerem essas parcelas para a história via determinante biológica, subordinam as ações ou participações delas a uma planta básica pré-dada de atuação que, no seu limite superior, jamais ultrapassa a linha que demarca a natureza da cultura. Neste sentido, a participação dessas populações nos acontecimentos fundamentais que, a partir do sertão, fundaram a nação e definiram sua trajetória rumo à construção de uma

\footnotetext{
5 Sabemos que existem numerosas particularidades e especificidades nos discursos do pensamento social brasileiro que distinguem índios e negros, mamelucos, cafusos e uma série de outras categorias étnicas nos sertões, atribuindo a cada uma delas valores, significados e papéis diferenciados na constituição e caracterização do espaço e na história sertaneja. Não nos furtaremos a considerar aqui, quando necessário aos objetivos do trabalho, as implicações destas distinções. Todavia, a particularidade do campo discursivo sertanejo que opõe e se estrutura em relações de poder determinadas, a partir de dicotomias como Civilização X Barbárie, Natureza X Cultura, Litoral X Sertão, e outras, traz sempre o mesmo conteúdo subjacente: a separação, oposição e complementaridade racial entre brancos, de um lado, e não-brancos, agrupados genericamente, de outro. Isso nos autoriza a trabalhar com a categoria ampla de "não-brancos", na tentativa de surpreender e iluminar aquelas relações, assumindo um ponto de vista que é ao mesmo tempo analítico e político, por outro lado, assumir o variado espectro de "cores" constitutivo do mito racial brasileiro como ponto de partida analítico seria recusar uma autonomia da análise em relação ao próprio mito, seria aceitar falar de dentro dele. Equivaleria, no limite, a falar por ele.
}

PRISMAS: Dir., Pol.Pub. e Mundial., Brasília, v.3, n, 2, p 427-454, jul/dez.2006 
civilização brasileira, quando não é vista como obstáculo a esta caminhada, é considerada, como fator de atraso e de retenção desta marcha. Quando consideradas positivas, suas ações são descritas como meras participações coadjuvantes, em tudo figurativas, num texto em que o grande herói é sempre o homem branco. Vistas desde o palco da história, as populações não-brancas são sempre figurantes. Em geral são apresentadas apenas como observadoras. Observadoras privilegiadas, é verdade, posto que sempre na primeira ou na segunda fila (pois seria impossível esconder sua presença), mas sempre observadoras. Desçamos então a história, aqui, do palco para a platéia.

Ana Flávia Moreira dos Santos, num inteligente trabalho sobre o elemento indígena no sertão norte-mineiro, pondera que é possível identificar, nos textos, uma associação quase natural entre o índio e o espaço sertanejo, isto é: se o elemento indígena se torna de fato, nas obras fundadoras do pensamento social sobre o sertão, um signo essencialmente caracterizador de tal campo discursivo, por outro lado, quase sempre ocupa também, neste universo, uma posição marginal. Nas palavras da autora: se "entretanto, tal associação pode ser freqüentemente detectada, parece, à primeira vista, estar marcada por uma contradição. Por um lado, é o elemento indígena [ou o não-branco. Acréscimo nosso] uma das categorias constitutivas do campo simbólico ‘acionado' pelo termo sertão. Por outro, sempre (ou quase sempre) ocupa, neste universo um lugar marginal; dir-se-ia que, embora

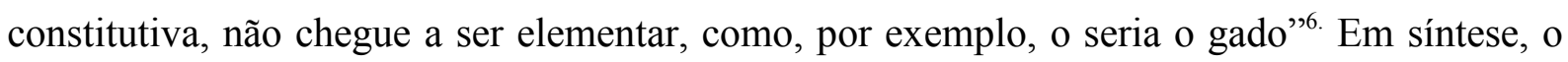
índio é um dado natural do sertão, porém sempre aparece como um elemento marginal no seu interior.

No caso específico do negro, ao contrário de toda a evidência e documentação histórica, é-lhe negada freqüentemente, nestes discursos, qualquer importância ou contribuição, mesmo marginal, quer na formação da composição étnica sertaneja, quer na participação histórica ou mesmo na formação da cultura do sertão. Quando muito, reconhecelhe uma presença diminuta no sertão, negando-lhe, todavia, qualquer influência histórica civilizacional real. Numa palavra, o negro no sertão é uma realidade invisível7 Invisível sim, porém realidade, pois, apesar de considerá-lo um agente ou elemento quase nulo, o negro permanece presente nos textos, assim como as considerações sobre seu papel e atuação.

\footnotetext{
${ }^{6}$ SANTOS, Ana Flávia Moreira O elemento indígena no sertão: Considerações sobre o Sertão Norte-Mineiro , Belo Horizonte, 1994, Mimeografado, p.. 1.

${ }^{7}$ Boaventura Leite assinala essa tendência no seu trabalho sobre a presença dos viajantes em Minas Gerais. A autora diz: "A obra de Wied-Neuvied, Viagem ao Brasil, praticamente não menciona a população escrava e liberta de Minas Gerais. Quem lê seu livro nunca poderá imaginar quem são os habitantes de Minas. Naturalista por excelência, o príncipe de Neuvied reservou o seu diário de campo apenas para registrar o cenário 'natural' do país, incluíndo nele os indígenas". LEITE, Ilka Boaventura. Antropologia da viagem: escravos e libertos em Minas Gerais no século XIX. Belo Horizonte: UFMG, 1996, p. 24.
}

PRISMAS: Dir., Pol.Pub. e Mundial., Brasília, v.3, n, 2, p 427-454, jul/dez.2006 
Como então refletir sobre o deslocamento marginal, ou mesmo a invisibilidade dessas populações a partir de sua relação com uma região (o sertão) definidora ou constituidora de um campo simbólico articulador de uma das identidades mais valorizadas por grande parcela do pensamento social brasileiro? Como trabalhar, portanto, com essa "aparente contradição"?

A exploração dessa contradição será, em nosso trabalho, uma preocupação fundamental. Exploraremos as categorias fundamentais e as matrizes elementares desses discursos para nelas encontrar os significados que iluminam esta aparente contradição. Vale dizer, exploraremos, nos assuntos condizentes com os objetivos do trabalho, as bases e os pressupostos raciais em que se assenta e se estrutura o pensamento social brasileiro, em relação a uma região simbolicamente definida e historicamente caracterizada como "Sertão". O objetivo aqui será, antes de tudo, perceber e acompanhar, nas obras fundadoras do pensamento social brasileiro que têm o sertão como espaço geográfico-simbólico privilegiado para a definição da nacionalidade ${ }^{8}$ o encadeamento dos valores e significados que incluem (e como incluem?) ou excluem elementos definidores fundamentais (como raça ou povo, no caso o negro ou os não-brancos) da "legítima história da nação" ou da nacionalidade.

A importância dessa reflexão se encontra, acredito, na possibilidade de uma reavaliação dos papéis, da contribuição e da experiência histórica do negro no sertão, em relação ao conjunto da história e da historiografia do negro no Brasil.

Para enfrentarmos tais objetivos, fazem-se necessárias algumas considerações metodológicas. Em primeiro lugar, entendemos estes discursos do pensamento social brasileiro como mitos de fundação da nação e da nacionalidade, na medida em que se perguntam sobre ou respondem a questões como a origem, a evolução e os destinos da nação

\footnotetext{
8 “'Sertão' é umas das categorias mais recorrentes no pensamento social brasileiro, especialmente no conjunto de nossa historiografia. Está presente desde o século XVI, nos relatos dos curiosos, cronistas e viajantes que visitaram o país e o descreveram, assim como, a partir do século XVII, aparece nas primeiras tentativas de elaboração de uma história do Brasil, como a realizada por Frei Vicente do Salvador. No período compreendido entre as últimas décadas do século XIX e as primeiras do século XX, mais precisamente entre 1870 e 1940 , 'sertão' chegou a constituir categoria absolutamente essencial (mesmo quando rejeitada) em todas as construções historiográficas que tinham como tema básico a nação brasileira”. AMADO, Janaína. Região, sertão, nação, In: Estudos Históricos, Rio de Janeiro, vol. 8, n. 15, 1995, p.. 145/146.

PRISMAS: Dir., Pol.Pub. e Mundial., Brasília, v.3, n, 2, p 427-454, jul/dez.2006 
brasileira $^{9}$. Em segundo lugar, propomos a análise do pensamento social exclusivamente centrada em sua versão culta, posto que esta tem como objetivo precípuo totalizar a explicação da nacionalidade, tornando-a uma estrutura permanente, fonte de entendimento do país e buscando no passado elementos para análise do presente e para a projeção do futuro da nação. Tal esquema de eficácia permanente, como diz Lévi-Strauss, permite interpretar a estrutura social brasileira de qualquer tempo (seja passado, presente ou futuro), a partir dos mesmos eventos fundantes. Neste exato sentido, desdobra sobre si uma narrativa que é essencialmente mítica.

Decorre disso que, se nos propomos a analisar a literatura de ficção e imaginação da nacionalidade brasileira desse ponto de partida, é necessário, portanto, aproximarmo-nos dos autores do pensamento social brasileiro como quem se aproxima de nativos, os quais costuram pacientemente um intrincado mito de origem. Suas obras serão entendidas como organizadoras de significados de originalidade, autenticidade e essencialidade da nação brasílica. À maneira mesmo de uma narrativa mítica, tais obras discorrem sobre pessoas e regiões articuladas no interior de eventos considerados fundantes da comunidade nacional, e projetam para o futuro um destino das pessoas, das regiões e da nação inscrito de antemão nas sua próprias origens.

Entendidas as representações do pensamento social como conteúdo imaginativo, como interpretações sobre a história do sertão e fundação da nação, isto é, como mito, nada impede que voltemos sobre elas o mesmo olhar etnográfico que se propõe a compreender qualquer outro conjunto estruturado de significados. Por assim ser, os intelectuais (exímios produtores de mito) serão aqui encarados, à maneira etnográfica, como nativos criadores de representações sociais, produtores e reprodutores de interpretações, de mitos de fundação da comunidade imaginada como Brasil. Serão, portanto, eles e suas obras entendidos como informantes, sempre orientados no sentido de ordenar as representações nativas embasadoras de formulações, de projetos de nação e de povo no Brasil.

\footnotetext{
${ }^{9}$ Para Lévi-Strauss, 'um mito diz respeito, sempre, a acontecimentos passados: 'antes da criação do mundo', ou 'durante os primeiros tempos'. [...] Mas o valor intrínseco atribuído ao mito provém de que estes acontecimentos, que decorrem supostamente em um momento do tempo, formam também uma estrutura permanente. Esta se relaciona simultaneamente ao passado, ao presente e ao futuro. [...] Nada se assemelha mais ao pensamento mítico que a ideologia política. Em nossas sociedades contemporâneas, talvez esta tenha se limitado a substituir aquele". Ainda para o mesmo autor, e num sentido ainda mais importante para os objetivos do nosso trabalho, os mitos se referem "a uma seqüência de acontecimentos passados, cujas conseqüências longínquas se fazem, sem dúvida, ainda sentir através de toda uma série não-reversível, de acontecimentos intermediários. [...] Seqüência de acontecimentos passados, mas também esquema dotado de uma eficácia permanente, permitindo interpretar a estrutura social [...] atual, os antagonismos que nela se manifestam, e entrever os lineamentos da evolução futura". LÉVI-STRAUSS, Claude. Antropologia estrutural. Rio de Janeiro, Tempo Brasileiro, 1989, p.. 241.
} 
Exatamente por isso, consideramos aqui muito pouco produtiva a discussão de se são "falsas" ou "verdadeiras" estas interpretações, se algumas correntes interpretativas ou escolas são mais "realistas" ou "adequadas" que outras, no esforço de captar com maior acuidade a "verdadeira essência" da realidade nacional. Ao contrário desse tipo de enfoque, o que nos interessará nesse material é a possibilidade de apreciação dos significados persistentes e articulados que compõem algumas das obras mais importantes da narrativa culta sobre o povo, o sertão e a nacionalidade ${ }^{10}$.

Dito isso, podemos agora definir o que se entende neste trabalho como "pensamento social", quais os critérios de inclusão e de exclusão de intelectuais e obras neste conceito. Acompanharemos aqui o traçado delineado por Vidal e Souza. Para a autora, os textos que, a partir desses pressupostos, circunscreveriam o conceito de "pensamento social" seriam aqueles que melhor exprimissem "a nacionalidade dentro de uma totalidade discursiva que articula autor, temática e público voltada para conhecer/redescobrir o Brasil enquanto amplidão espacial e multidão de tipos sociais. Assim se caracteriza o grupo de autores que são sociógrafos representativos do pensamento social brasileiro"11.

Está claro que um conceito como o de pensamento social, articulado especificamente deste modo, constitui-se num universo de autores e obras virtualmente impossível de ser exaustivamente analisado aqui, e nem este é nosso objetivo. Do imenso conjunto de obras e autores que, a partir dessa definição, poderiam ser incluídos dentro do conceito de "pensamento social", selecionamos apenas alguns trabalhos, ao nosso ver significativos para compreendermos o processo de elaboração da variável racial nas estruturas de interpretações e representações intelectuais do sertão.

\footnotetext{
${ }^{10}$ Tal entendimento, sobre o qual aqui se apoiarão as abordagens do pensamento social brasileiro, faz uma opção clara por definir a natureza mítica das narrativas em seu sentido antropológico, isto é, como estrutura de referência cultural, portanto, pouco sentido faz a busca pela veracidade ou falsidade desta ou daquela versão da brasilidade. Cada versão será considerada como " "uma narrativa que dramatiza a visão de mundo e a experiência em uma constelação de poderosas metáforas' ", e que "não tem, portanto, o sentido de 'falsidade' ou 'mentira'; ao contrário [...] Mitos filtram da experiência coletiva elementos que um grupo deseja lembra e ver lembrados, e os transformam em símbolos. A escolha desses elementos não é casual; como a memória e a história, o mito é seletivo. Os elementos escolhidos, as 'idéias básicas' [...] devem expressar noções e emoções com as quais a maioria do grupo se identifica, por isso os mitos representam visões de mundo, lidam com questões fundamentais". AMADO, Janaína. Construindo mitos: A conquista do oeste no Brasil e nos EUA In: PIMENTEL, Sidney Valadares e AMADO, Janaína (Org). Passando dos limites. Goiânia: UFG, 1995, p. 54.

${ }^{11}$ Para a autora ainda, pensamento social "aqui está como uma classificação para os textos que cuidam de demarcar no tempo e no espaço as características distintivas da nação brasileira. Quando e onde começam a existir o Brasil e por quais caminhos tem evoluído a formação nacional são as temáticas de inspiração para se construir modelos explicativos do país, p.or esse núcleo de preocupação, distribuem-se obras que expõem descrições-pareceres da situação brasileira, as quais podem ser desenvolvidas sob perspectivas diversas de construção da realidade pensada. Ou seja, há múltiplas linguagens utilizadas para opinar sobre um só e mesmo tema: a nação brasileira". VIDAL E SOUZA, Candice. A pátria geográfica: sertão e litoral no pensamento social brasileiro. Goiânia: UFG, 1997, p.. 21.
}

PRISMAS: Dir., Pol.Pub. e Mundial., Brasília, v.3, n, 2, p 427-454, jul/dez.2006 
Sob a aparência de diversidade caótica de autores e propostas de compreensão do Brasil, subjazem relações de significados que fazem emergir um estreito parentesco entre os textos. Aqui, diferentemente de "apontar a inserção dos intelectuais na sociedade como fator relevante para a explicação de desenvolvimento de ideologias da construção da nacionalidade e de representações diversas sobre a vida social"12 e aí encontrar semelhanças e aproximações, o que importa é considerar a ideologia como um sistema simbólico em que é possível perceber a posição e o lugar que os seres humanos conferem a si, aos seus constructos e aos outros homens na sociedade ${ }^{13}$.

Finalmente, alertamos para a possibilidade de a ordenação das obras e idéias não se apresentar necessariamente em uma seqüência cronológica estrita. Isto também deriva dos pressupostos acima apresentados. Se a análise do pensamento social deverá ser desenvolvida no sentido de apreender a sistemática dos conjuntos articulados de idéias, importa antes perceber o parentesco entre estas obras e idéias a partir de sua consistência interna, sendo sua localização cronológica na história do pensamento social uma questão secundária.

\section{O Sertão como Campo Simbólico}

Sertão, antes de tudo, é um termo que designa uma região ou vários tipos de regiões ${ }^{14}$. Pretendem muitos dos que o utilizam apenas que o conceito individualize uma dada realidade natural ou geográfica existente e observável empiricamente. Acreditam reproduzir fiel e objetivamente uma natureza, sem o concurso ou a interferência de valores ou pontos de

${ }^{12}$ Este é um dos eixos apontados explicitamente por Nísia Trindade Lima no seu trabalho já citado, p.. 14.

${ }^{13}$ Exatamente por isso, aproprio-me do que disse Vidal e Souza: "Encontrar a unidade desse conjunto de obras e autores" é conseguir perceber que "do coletivo de sociografias vai-se reconhecendo a existência de uma formação discursiva plenamente constituída que se reproduz a cada novo empreendimento de totalização narrativa da questão nacional. [...] E, seguramente, uma das direções, na qual se percebe que a sociografia brasileira se mostra sistêmica, é a problematização de continente e conteúdos da terra destinada a ser nacional". [...] Ou seja, é possível acreditar que a formulação culta da problemática nacional simultaneamente cria e recupera temáticas e padrões explicativos persistentes, sobrepostos à variedade dos autores e, de certo modo, independentes das desigualdades de prestígio, habilidade estilística ou competência analítica dos escreventes da brasilidade Aqui, a repetitividade das fórmulas narrativas próprias das falas míticas aparece nos textos totalizadores de uma idéia de Brasil, na forma de temáticas paradigmáticas e de modos de ver recorrentes, que funcionarão como pistas de interpretação". É exatamente neste sentido, portanto, que "o nacionalismo deve ser compreendido pondo-o lado a lado, não com ideologias políticas abraçadas conscientemente, mas com sistemas culturais amplos que o precederam". Op. Cit., p. 27, 31 e 35.

${ }^{14}$ Neste sentido específico, como indica Cristóvão, "o sertão celebrado pela literatura toma como ponto de partida os dados objetivos da região mediterrânea pastoril onde a criação de gado estabilizou as populações adaptadas ao meio. Diversifica-se em sub-regiões onde o criatório constituiu, sob o ponto de vista econômico da forma de ocupação humana, o elemento mais caracterizador. Um mesmo sertão se reconhece, por isso, no ceará, no Rio Grande do Norte, na Paraíba, em Pernambuco, em Sergipe, nas Alagoas, na Bahia ou em Minas Gerais. A ponto de o devermos entender, acima de tudo, como uma região do interior, de criação de gado, desértica, mais ou menos estacionado no passado que se recorda como santuário ou reserva das tradições ancestrais, repositório venerado da linguagem e costumes antigos". CRISTÓVÃO, Fernando. A transfiguração da realidade sertaneja e sua passagem a mito: a divina comédia do sertão. In: Revista da USP:Dossiê Canudos. São Paulo, No. 20, Dezembro, Janeiro, Fevereiro 93-94, p.. 45. 
vista ideológicos. Acreditam "representar" a natureza tal como ela é, ou tal como se nos apresenta aos olhos.

Trabalharemos neste artigo com a noção de que "sertão" é muito mais do que apenas um termo ou vocábulo caracterizador de uma região específica. É, acima de tudo, um campo simbólico, uma região de significados e relações de sentido estruturadas por um conjunto mais ou menos aberto de categorias cognitivas que, muito mais do que reproduzir ou caracterizar objetivamente uma unidade geográfica, a constrói simbolicamente, sempre no sentido de produzir uma narrativa da formação histórica do país, da fundação da nação ou da construção da identidade nacional, que retira do centro e desloca ideologicamente para a periferia do discurso as populações não-brancas.

Dentre o material bibliográfico disponível (um universo virtualmente ilimitado), escolhi para trabalhar inicialmente a literatura de viagem, mais precisamente três de seus principais autores, que passaram pela região sertão e a ela se referenciaram. Estes autores são Spix e Martius e Saint Hilaire.

Tal recorte explica-se pela marcada ambição presente na literatura de viagem, de uma forma geral e em particular nestes autores, no sentido de alcançar uma objetividade, de reproduzir fiel e exatamente o que se está vendo. Este ponto nos permitirá discutir, ao longo do texto, alguns aspectos relativos à teoria da percepção e da representação social. Por outro lado, a análise da literatura de viagens ${ }^{15}$ possibilitará também avaliar o impacto produzido pela obra destes três autores nos modos de sentir e interpretar o Brasil em uma longa tradição

\footnotetext{
${ }^{15}$ As obras dos viajantes podem ser entendidas em constante deslocamento entre dois pontos básicos, sofrendo, portanto, de uma natural ambivalência. São resultados, ao mesmo tempo, de um "pensamento estrangeiro" e de um "pensamento nacionalizado". São, obviamente, produtos de um pensamento estrangeiro na medida em que o botânico alemão ou o naturalista francês são pessoas dotadas de equipamentos culturais diferentes e, nesta medida, trazem no olhar um patrimônio anterior que condiciona o modo de observar e entender. Todavia, podem ser percebidas como um "produto" ou bem cultural nacionalizado na medida em que, como muito bem coloca Boaventura Leite, "os bens culturais acumulados pelas viagens tornam-se nacionais, quando e enquanto estão intimamente vinculados a correntes culturais e científicas, e quando estão estreitamente vinculados à aplicação e à consolidação dos interesses das nações envolvidas”. Op. Cit., p. 57e58. Tais obras, trazendo sempre a marca dessa ambivalência, ao serem amplamente consumidas pelo pensamento social brasileiro do século XIX, ajudaram a construir nele toda uma maneira de sentir e interpretar o povo brasileiro permeada, portanto, das conseqüências desse deslocamento. Os intelectuais brasileiros assumiam uma perspectiva estrangeira de olhar o povo brasileiro, ao mesmo tempo em que não podiam fugir do fato de que era com aquele mesmo povo, e não com outro, afinal, que tinham de pensar um país. Nesta medida, o povo brasileiro aparecia por vezes aos intelectuais brasileiros como "outro", "estrangeiro", estranho dentro do território nacional, e, outras vezes, eram os próprios intelectuais que se sentiam deslocados dentro de seu próprio país.

PRISMAS: Dir., Pol.Pub. e Mundial., Brasília, v.3, n, 2, p 427-454, jul/dez.2006 
sócio-histórica e literária de "intelectuais patriotas"16. Em seus textos e obras fundadoras do pensamento social brasileiro sobre o sertão, estes últimos definiram, em largos traços, as balizas, os matizes e os contornos do que se compreendia ser o lugar do negro na sociedade brasileira, e, no limite, do que deveria ser o brasileiro.

A partir daí passaremos à discussão de alguns dos "interesses" e das estratégias ideológicas e de estilo que nessas obras permitiram empurrar as camadas não-brancas formadoras da população sertaneja para a margem de um conjunto de discursos centrados no sertão, formulando critérios de pertencimento coletivo e utilizando diversos códigos demarcadores de inclusão e exclusão.

No caso específico discutido neste capítulo, a invisibilidade e o deslocamento marginal dos não-brancos para a periferia das estruturas de força e categorias positivas de valor, articuladas no interior do campo simbólico do sertão, traduziram-se nos arranjos e rearranjos dos núcleos de significados estruturantes da imagem de nação. Isto é, as estruturas de significados projetadas por estas obras definiram, autorizaram, veicularam e popularizaram uma estrutura discursiva básica, marco dentro do qual poderia ser pensada como continua sendo pensada até hoje, por grande número de autores a imagem ideal de nação.

Navegando dentro dos quadros e limites desta estrutura estabelecida pelo pensamento social romântico de meados do século XIX, os trabalhos de parte das gerações futuras de historiadores, escritores, sociólogos e intelectuais, de uma forma geral, impuseram um padrão interpretativo da sociedade brasileira que, no mais das vezes, obnubilou a participação ativa desses grupos nos nossos processos históricos mais importantes.

Por fim, não se defenderá aqui, em momento algum, nem a inevitabilidade nem a ausência de alternativas produzidas, tanto ontem como hoje, a esta estrutura discursiva romântica interpretativa da sociedade brasileira. Interessa-nos iluminar algumas das principais estruturas simbólicas de força, organizadoras de alguns dos discursos fundadores do campo semântico do sertão primeiramente nos textos dos viajantes estrangeiros, Saint-Hilaire, Spix e Martius, e depois em alguns dos textos mais importantes da intelectualidade brasileira dos séculos XIX e XX. Interessa-nos também vislumbrar como estas estruturas foram manipuladas pelo pensamento social brasileiro, como, em função de seus "interesses", principalmente de invenção de uma idéia de nação determinada, operou-se, em relação às

\footnotetext{
16 "Esta sociografia pode ser identificada como produto da prevalência contínua e ampliada do espírito nacional. Sinaliza a consolidação de uma prática narrativa pela qual se nota que o pensador nativo é o cidadão responsável por nomear, diagnosticar e propor o real nacional. A literatura de ensaios brasilianos se põe a mapear o país sob a determinação de que este saber-radiografia é também roteiro de ação. Ensinar o que há no Brasil para os brasileiros vem a ser o estímulo maior do artesanato intelectual dos inventores da nação". VIDAL E SOUZA, Candice. Op. Cit., p. 23.
}

PRISMAS: Dir., Pol.Pub. e Mundial., Brasília, v.3, n, 2, p 427-454, jul/dez.2006 
populações não-brancas constitutivas da realidade nacional e sertaneja, um deslocamento no interior do campo discursivo para regiões de significados específicos e marginais em termos de valores positivos constitutivos.

\section{O Sertão dos Viajantes}

A primeira afirmação que chama a atenção do leitor de Viagem pelas províncias do Rio de Janeiro e Minas Gerais ${ }^{17}$, logo à página 04, é a seguinte: “permitir-me-ei poucas reflexões; direi o que tiver visto, procurando apresentar os fatos sob o seu aspecto real, deixando, na maioria das vezes, ao leitor, tirar por si as conclusões. Levei o escrúpulo da exatidão ao máximo; e, devo confessá-lo, preocupei-me mais em pintar corretamente o que observei do que em burilar o estilo".

Suponho que esta imagem de isenção, imparcialidade, neutralidade e objetividade científica tenha solidificado nos espíritos dos seus contemporâneos uma profunda confiança na honestidade intelectual e na capacidade científica do autor. Uma prova cabal do enraizamento e poder, vigente até hoje, dessa imagem entre nossa intelectualidade está no prefácio de Américo Jacobina Lacombe à obra de Moema Parente Augel, onde afirma terem sido "raros os viajantes que vieram revestidos de um espírito isento e científico para observar e julgar o espetáculo do país percorrido. Ao lado de um Martius, um Saint-Hilaire e um Burton, homens de alto gabarito cultural e isenção moral, pululam os contrabandistas ressentidos, como Lindley, os malogrados em seus ideais de 'fazer a América', como Expilly e os frustrados como Schlichtorst" $"$.

Todavia, por mais crítico que se possa ser em relação a esta distinção de isenção, objetividade e imparcialidade, com a qual normalmente se identificam alguns dos viajantes ou suas obras, seria limitado e simplista considerá-la simplesmente um embuste ou fantasia. Até mesmo pelo fato de que o estilo literário de Saint-Hilaire, sobre o qual aliás o autor tem perfeito domínio, reforça muito esta impressão. O esforço sincero para atingir a plena objetividade na descrição geográfica fica patente na seguinte delimitação das fronteiras que, entende o autor, demarcam o sertão:

O sertão compreende, nas minas, a bacia do S. Francisco e dos seus afluentes, e se estende desde a cadeia até os limites ocidentais da província. Abarca, ao sul, uma pequena parte da comarca do Rio das Mortes, a leste, uma imensa porção das Comarcas de Sabará e do Serro Frio, e finalmente, a

\footnotetext{
17 SAINT-HILAIRE, Auguste de. Viagem pelas províncias do Rio de Janeiro e Minas Gerais. São Paulo: Itatiaia, 1975.

${ }^{18}$ AUGEL, Moema Parente. Visitantes estrangeiros na Bahia. São Paulo: Cultrix $\backslash$ MEC, 1980, prefácio.

PRISMAS: Dir., Pol.Pub. e Mundial., Brasília, v.3, n, 2, p 427-454, jul/dez.2006 
oeste, toda a comarca de Paracatu situada ao ocidente do São Francisco. Essa imensa região constitui assim cerca de metade da província de Minas, e se estende, aproximadamente, desde os 13 o até os 21 o de latitude; mas não se deve pensar que o sertão se restrinja à província de Minas Gerais; prolongase pelas da Bahia e Pernambuco, e a província de Goiás, pela qual se continua, não é ela toda senão um imenso deserto. ${ }^{19}$

A descrição geográfica objetivista de Saint-Hilaire assinala ainda um pequeno detalhe. Detalhe, aliás, muito significativo no contexto de sua fala:

O nome de sertão ou deserto não designa uma divisão política de território; não indica senão uma espécie de divisão vaga e convencional determinada pela natureza particular do território e, principalmente, pela escassez de população. ${ }^{20}$

A ambição objetivista do autor neste trecho fica, portanto, definitivamente estabelecida, quando remete para o âmbito das determinações da natureza algo que é próprio de uma atividade essencialmente humana: a capacidade inter homini de acordar convenções. Entretanto, para ele está claro: a "divisão vaga e convencional” do que se individualiza como sertão é, antes de tudo, “determinada pela natureza particular do território". Nada, portanto, de fronteiras ou delimitações geográficas socialmente estabelecidas, nada de recortes convencionados intelectual e imaginariamente, senão divisões ${ }^{21}$ naturalmente dadas.

Todavia, ainda no mesmo trecho, Saint-Hilaire abre uma brecha para que o leitor um pouco mais atento desconfie de tão rigorosa objetividade. Apesar de para ele, como vimos, o sertão obedecer prioritariamente a critérios de delimitação e definição naturais, ultrapassando convenções sócio-políticas, seu texto finaliza reintroduzindo o elemento

${ }^{19}$ SAINT-HILAIRE, Auguste de. Op. Cit., p. 307.

${ }^{20}$ Ibidem, p. 307.

21 "A etimologia da palavra região (regio), tal como a descreve Emile Benveniste, conduz ao princípio da divisão, ato mágico, quer dizer, propriamente social, de diacrisis que introduz por decreto uma descontinuidade decisória na continuidade natural (não só entre as regiões do espaço mas também entre as idades, os sexos, etc.). Regere Fines, o ato que consiste em 'traçar as fronteiras em linhas retas', em separar 'o interior do exterior', o reino do sagrado do reino do profano, o território nacional do território estrangeiro', é um ato religioso realizado pela personagem investida da mais alta autoridade, o rex, encarregado de regere sacra, de fixar as regras que trazem à existência aquilo por elas prescrito, de falar com autoridade, de pré-dizer no sentido de chamar ao ser, por um dizer executório, o que se diz, de fazer sobrevir o porvir enunciado. A regio e suas fronteiras não passam do vestígio apagado do ato de autoridade que consiste em circunscrever a região, o território (que também se diz fines) legítima, conhecida e reconhecida, das fronteiras e do território, em suma, o princípio da divisão legítima do mundo social. Este ato de direito que consiste em afirmar com autoridade uma verdade que tem força de lei é um ato de conhecimento, o qual, por estar firmado, com todo o poder simbólico, no reconhecimento, produz a existência daquele que enuncia (a auctoritas, como lembra Benveniste, é a capacidade de produzir que cabe em partilha ao autor). $\mathrm{O}$ autor, mesmo quando só diz com autoridade aquilo que é, mesmo quando se limita a enunciar o ser, produz uma mudança no ser: ao dizer as coisas com autoridade, quer dizer, à vista de todos, publicamente e oficialmente, ele subtrai-as ao arbitrário, sanciona-as existir como dignas de existir, como conforme a natureza das coisas, 'naturais'. Ninguém poderia hoje sustentar que existem critérios capazes de fundamentar classificações 'naturais' em regiões 'naturais', separadas por fronteiras 'naturais'. A fronteira nunca é mais do que um produto de uma divisão a que se atribuirá maior ou menor fundamento na 'realidade' segundo os elementos que ela reúne, tenham entre si semelhanças mais ou menos numerosas e mais ou menos fortes", BOURDIEU, Pierre O poder simbólico. Rio de Janeiro/Lisboa: Bertrand Brasil/Difel, 1989, p. 113 e 114.

PRISMAS: Dir., Pol.Pub. e Mundial., Brasília, v.3, n, 2, p 427-454, jul/dez.2006 
humano, ao assinalar que, sobretudo "pela escassez de população", "não é ela toda [a região] senão um imenso deserto". Este fato fica também muito claro em Spix e Martius quando, da mesma forma, assinalam: "Achamo-nos agora no sertão, como denominam os mineiros a vastidão deserta, na sua linguagem usual". ${ }^{22}$

A brecha que se abre neste pretenso, mas ainda assim sólido, discurso objetivista, indicado sobretudo pela referência ao "deserto" e à "vastidão", é o fato de que aqui o próprio discurso expõe e deixa nítidos seus meandros. O que deseja estabelecer Saint-Hilaire, além das coordenadas geográficas, é sobretudo um conteúdo social e simbólico. Assim, como aponta Ana Flávia Moreira Santos na obra destes viajantes, “[...] os marcos materiais embora surpreendentemente precisos estão contextualizados dentro de uma simbologia, esta sim definidora da região. O sertão em Minas não é a área da bacia do São Francisco e afluentes, suas terras chãs, mas sim o deserto, o vazio social, a não presença da mineração [...]. O traço unificador que se entende por Goiás é o vazio, e não uma condição da natureza. Esta, diria, mesmo quando equacionada à figura 'sem cor' dos marcos geográficos, já está simbolicamente investida". 23

Eis, portanto, a primeira grande categoria cognitiva e nucleante presente nos discursos dos viajantes aqui abordados, um dos eixos que compõem, organizam e articulam o campo simbólico configurado pelo sertão: o "vazio", o "deserto". Tal categoria faz parte de um conjunto mais ou menos limitado de categorias cognitivas, pelo menos no que tange às categorias mais elementares que estruturam os discursos sobre o sertão, as quais, articuladas entre si, formam um texto cultural sempre aberto e virtualmente ilimitado, no sentido de abarcar ou incluir novos significados, ou arranjar e rearranjar os seus elementos de base ${ }^{24}$.

Assim, a natureza, que a literatura de viagem de Saint-Hilaire e Spix e Martius pretende que seja só natureza mesmo, que se auto-defina e se auto-delimite, é, ao contrário, simbolicamente investida pelo seu, talvez, principal elemento humano caracterizador: o "vazio" social, a "vastidão" e as "solidões",25. Estes significados se constituem, sobretudo, em categorias cognitivas que organizam e estruturam os discursos sobre os sertões.

\footnotetext{
22 SPIX E MARTIUS. Viagem pelo Brasil, São Paulo: Melhoramentos/Mec, 1976, p. 65.

${ }^{23}$ SANTOS, Ana Flávia Moreira. Op. Cit., p. 12.

24 "Percebo a cultura ainda como um sistema onde diferentes núcleos de representação estão em comunicação uns com os outros, como que formando uma rede de significados. Essas categorias nucleantes agregam conjuntos de significações, os quais, em sua comunicação dentro do universo de representações, se articulam e compõe uma totalidade. Essas categorias são também nucleantes no plano do discurso, isto é, elas organizam o discurso e a cultura pode ser vista como um conjunto de discursos". WOORTMANN, Klaas. Com parente não se Neguceia. In: Anuário Antropológico 87. Brasília, UnB/Tempo Brasileiro, 1990, p.. 23.

25 "Seria sair do quadro que me propus mencionar as aves que animam e embelezam as solidões do sertão". SAINT-HILAIRE, Auguste de. Op. Cit., p. 320.

PRISMAS: Dir., Pol.Pub. e Mundial., Brasília, v.3, n, 2, p 427-454, jul/dez.2006 
Marco Paulo Fróes Schettino, em um trabalho que explora a idéia de vazio na noção de sertão presente na literatura de viagem de Saint-Hilaire, assinala que “etimologicamente a palavra sertão deriva de desertão, forma através da qual os portugueses do século XVI, se referiam às áreas 'despovoadas' de outros continentes, África e Ásia. Desertões também foram as áreas 'despovoadas' do novo continente americano nas terras brasílicas, hoje sertões. Do latim clássico Serere, Sertanum ou trançado, entrelaçamento, embrulhado; desertum, o que sai da fileira, desertor, o que sai da ordem e desaparece; desertanum, lugar desconhecido para onde foi o desertor, estabelecendo a oposição entre o locus certo e o lugar incerto, desconhecido", e acrescenta que "a idéia de sertão", portanto, “traz em si esse rarefeito de homens, espaço onde o homem é relativizado, diminuído, diluído em meio a uma natureza exuberante que prepondera. Sertão é uma representação pouco humanizada, é uma alteridade, um vazio de homens". ${ }^{26}$

A força dessa idéia desumanizadora e essencialista do sertão, que despeja todo o peso da natureza sobre os poucos elementos humanos constituintes dos sertões, acaba, finalmente, por caracterizar de modo geral a ambos, os homens e o próprio sertão. Esta determinante estará ainda presente, mais de um século depois, na obra de um autor como Nelson Werneck Sodré. Sodré, em uma de suas primeiras obras, deixaria perceptível a força ainda intacta, no imaginário social, da capacidade de absorção e diluição que tem a natureza sertaneja, pela exuberância e poder do todo vazio que a caracteriza e se inscreve nas parcas possibilidades de humanização no sertão, sobre os que porventura foram caracterizados como seus filhos naturais:

Sobre o sertão paira a força impulsiva e bruta da natureza. Correndo chapadões e planícies baixas [...] o homem encontra apenas as forças obscuras que se abrigam na amplidão. Sente-se diminuído por elas, apesar de suas grandes reservas de energia. $\mathrm{O}$ meio físico, com o qual não comunga, aniquila-o, impõe uma supremacia tremenda. A própria fulguração da paisagem traz todos os sinais de divórcio absoluto. [...] Nas caminhadas solitárias, ou tocando as monótonas pontas de gado [...] o homem compreende, obscuramente e primariamente, a força poderosa, tirânica, dominadora do sertão. ${ }^{27}$

O sertão, com o vazio que o caracteriza, não é só uma natureza vazia de homens ou de sociedade, mas muito mais do que isso. Caracteriza um espaço no qual a própria humanização, subjugada e diluída por uma natureza sempre mais forte, dominadora e absorvente, é insuficiente, é débil. Tal característica equivale, no pensamento social, à própria

\footnotetext{
${ }^{26}$ SCHETTINO, Marco Paulo Fróes. A idéia de vazio na noção de sertão. Brasília, 1994. Mimeo, p.. 05.

27 WERNECK SODRÉ, Nelson. Oeste: ensaio sobre a grande propriedade pastoril. Rio de Janeiro: José Olímpio, 1941, p.132.
}

PRISMAS: Dir., Pol.Pub. e Mundial., Brasília, v.3, n, 2, p 427-454, jul/dez.2006 
inviabilidade da civilização. Por outro lado, se o sertão (apesar de todo o vazio e a natureza dominadora) parcialmente se viabiliza, é ainda e sempre pela irreprimível energia do desbravador. Este, todavia, ainda que se entregando a uma luta que, ao mesmo tempo, é antagônica e também simbiótica com o meio (o qual tem uma incomensurável força de absorção), não consegue em geral produzir, por conta disso, mais do que uma "civilização natural".

O deslocamento entre estas duas possibilidades civilização natural ou natureza civilizada, isto é, a possibilidade inscrita nos discursos sobre o sertão de representar ou atualizar ora uma civilização com forte presença da natureza, ou quase totalmente atravessada por ela (uma civilização natural), ora a representação de uma natureza passível de, em alguma medida, ser civilizada (uma natureza civilizada), é uma característica marcante desses discursos. Esta ambigüidade parece ser estrutural na narrativa, uma característica própria da constituição do campo simbólico organizado por "sertão". Assim, ora o espetáculo exuberante da natureza é visto em caatingas desfolhadas e campos ardidos do alto sertão, impróprios a toda vida humana civilizada, ora se manifesta em descrições em que os mencionados viajantes representam, por exemplo, as margens do São Francisco como quase um paraíso, convidativo, pronto, à espera dos impulsos civilizadores do homem diligente:

Julgamo-nos aqui transportados a um país inteiramente diverso. Em vez das matas secas, desfolhadas ou dos campos do alto sertão, vimo-nos de todos os lados cercados de matas virentes, que orlavam extensas lagoas piscosas. [...] Centenas de róseos colhereiros (Platalea ajaja, L.) perfilavam-se reunidos ao longo da margem e vadeavam lentos, revolvendo ativamente a lama com o bico. Em água mais funda, andam comedidos ali ao redor alguns graves jaburus e tuiuiús [...] perseguindo os peixes com os compridos bicos. ${ }^{28}$

A mesma ambigüidade apresenta-se no relato de Saint-Hilaire. Uma natureza que em determinados momentos e lugares é um "jardim”, em outros, aparece como uma tristeza só, "com um céu escaldante e a canícula do verão":

Os que falam do sertão garantem que ele se assemelha a um jardim, e essa comparação ficou até proverbial. Admito, efetivamente, que essa região possa ter $\mathrm{o}$ aspecto que lhe atribuem, quando os relvados estejam perfeitamente verdes, e as árvores e esses arbustos tão numerosos, tão vareados, fiquem cobertos de flores em geral tão vistosas; entretanto, por mais florido que seja, um jardim plantado quase pelo mesmo modelo durante um espaço de várias centenas de léguas, fatiga, finalmente pela monotonia. Mas qual o tédio que experimenta aquele que, como eu, percorre o sertão durante o tempo da seca, quando as campinas perderam o frescor, e a maior parte das árvores está despojada de folhas? Então um calor irritante abate o viajante; uma poeira incômoda ergue-se debaixo de seus passos, e algumas

${ }^{28}$ Spix e Martius. Op. Cit., p. 77.

PRISMAS: Dir., Pol.Pub. e Mundial., Brasília, v.3, n, 2, p 427-454, jul/dez.2006 
vezes mesmo, nem sequer encontra água para aplacar a sede. É toda a tristeza de nossos invernos com o céu escaldante e a canícula do verão. ${ }^{29}$

Muitos outros exemplos se poderiam dar das ambigüidades do que se considera "sertão". O campo de significados que constitui o "sertão" está totalmente saturado dessas ambigüidades ou dualidades. Paisagens desoladas compõem-se com e sucedem a jardins; secas abrasivas e inclementes alternam-se, nas descrições desses viajantes, a um clima que pode ser, à vezes, bastante úmido. Enfim, um quadro ou paisagem que, se em alguns momentos aponta para as inúmeras possibilidades do desenvolvimento e da plenitude da vida, em outros inscreve no seu interior signos anunciadores de morte.

E esse maravilhoso espetáculo nos teria ainda mais agradavelmente impressionado, se não nos ocorresse o pensamento de que a guerra, a eterna guerra, era a lei e misteriosa condição de toda existência animal. [...] Internamo-nos pela espessura de uma capoeira, e, apenas tínhamos seguido um quarto hora por ali, quando se nos patenteou o espetáculo de outra lagoa, sobre a qual pendiam espessos arbustos, toda tingida de vermelho pelos raios do sol poente e estendida tranqüila e melancólica. Ressoando ainda aos nossos ouvidos a algazarra daqueles habitantes do ar da primeira lagoa, estávamos transportados, como por magia, ao país da morte. Não aparecia uma só ave, reinava um silêncio sepulcral e nem o próprio ar abafadiço, que pairava misterioso sobre as águas negras profundas, movia um galho, uma folha. Admirados, volvemo-nos para o nosso guia, e ele nos explicou que essa lagoa era unicamente paragem de jacarés e vorazes piranhas. ${ }^{30}$

Parece-me então que a ambigüidade ou a dualidade do espaço sertanejo é própria de uma possibilidade dada ou inscrita numa estrutura narrativa muito particular, construída de tal forma que permite ou mesmo enfatiza o paradoxo. Tal característica da estrutura narrativa possibilidade dada pela disposição ou combinação particular dos elementos que compõem a configuração de categorias cognitivas mais elementares do campo simbólico permite, ao

\footnotetext{
${ }^{29}$ SAINT-HILAIRE, Auguste de. Op. Cit., p. 308.

${ }^{30}$ SPIX E MARTIUS. Op. Cit., p.78.

PRISMAS: Dir., Pol.Pub. e Mundial., Brasília, v.3, n, 2, p 427-454, jul/dez.2006
} 
mesmo tempo, a inclusão do ser e do não $\operatorname{ser}^{31}$. Permite, por isso, a inversão de significados, a depender de qual faceta é enfatizada. Dessa forma, as fronteiras ou limites do campo simbólico que conforma o sertão, as possibilidades de expressar ora o ser, ora o não ser, estão sempre virtualmente abertas, dependendo da disposição, combinação ou arranjo das categorias cognitivas elementares do campo $^{32}$. Organizada sobre esse campo, uma determinada estrutura narrativa pode prestar-se tanto para incluir como para excluir signos e significados, dependendo do momento, da circunstância e do interesse em fazê-lo, manipulando tal ou qual elemento, esta ou aquela categoria, articulando-as com outros signos e valores, formando uma textura de significados que esvazia a aparência de contradição dos paradoxos, ao mesmo tempo que estimula um atordoamento do senso crítico a perturbar permanentemente a análise.

Neste sentido, a fala de Riobaldo em "Grande Sertão Veredas" ilumina-se de sentido: "enfim, cada um o que quer aprova, o senhor sabe pão ou pães, é questão de opiniões . O sertão está em toda parte" ${ }^{33}$.

Uma ressalva, porém: apesar de ser um campo simbólico virtualmente aberto, o sertão é, todavia, organizado e estruturado em torno de alguns eixos ou categorias cognitivas nucleantes. A primeira delas (não se pretende aqui esgotá-las), como vimos acima, é a

\footnotetext{
${ }^{31}$ É possível que, à revelia do que pretendiam, Saint-Hilaire, Spix e Martius estivessem construindo, juntamente com um discurso científico e objetivista, uma poderosa narrativa literária. Talvez, a melhor forma de se aproximar dessa estrutura narrativa fosse abordá-la menos como discurso geográfico ou botânico e prioritariamente como uma narrativa de criação ou imaginação literária, p.ara Fernando Cristóvão, a explicação das múltiplas possibilidades de manipulação simbólica do referente (o sertão) nos discursos literários, da abertura e permissividade dessa estrutura narrativa é o fato, precisamente, de eles serem uma composição basicamente poética e ficcional, muito diferente de uma narrativa definida como geográfica ou antropológica, p.ara Cristóvão, "por mais diversificadas que sejam [...] a realidade de base que lhes empresta legitimidade de transfigurações-simbolizações do referente é uma só, e importa defini-la desde já: há um só sertão, concretizado em muitos sertões, porque o sertão, tal como outras referências geográficas, tem, nos escritos de criação literária, uma amplitude que não se compadece com os dados da geografia nem com os da antropologia cultural. É diferente e outro, tanto na quantidade quanto na qualidade, porque projeta o próprio homem através da simbolização estética. Contudo uma relação estreita o liga a essa realidade nos dados essenciais. Dir-se-ia que o fingimento poético, não querendo ser tão arbitrário como o signo lingüístico, guarda sempre as dimensões de uma representação proporcionada ao real: nem é convencional nem é servil, antes reúne a solidariedade à independência, tal como as variações musicais ilustrando um tema". CRISTÓVÃO, Fernando. Op. Cit., p. 44 e 45.

32 "Propõe-se, assim, que o imaginário que recobre sertão, fronteira e nação tenha conservado sua qualidade polissêmica e a sua fluidez social e histórica. Desse modo, é que se poderá compreender em parte a eficácia simbólica do sertão no pensamento brasileiro e suas reverberações em vários contextos e grupos sociais diferenciados, percebendo-o como um organizador de idéias e práticas". VIDAL E SOUZA, Candice. Crescer para dentro: O imaginário da fronteira no pensamento social brasileiro. Discursos Intelectuais e Políticos, Brasília, Março de 1994, mimeo.

33 ROSA, João Guimarães. Grande sertão veredas. Rio de janeiro: Nova Aguilar, 1994, p.11.

PRISMAS: Dir., Pol.Pub. e Mundial., Brasília, v.3, n, 2, p 427-454, jul/dez.2006 
categoria de vazio ou deserto. A segunda, a de civilização-litoral/sertão-barbárie. Estas e outras, enfatizamos, não são fechadas, mas, ao contrário, interpenetrantes e intercambiantes ${ }^{34}$.

Em torno da primeira, até agora exploramos suas apropriações e possibilidades cognitivas e discursivas nos escritos de Saint-Hilaire e Spix e Martius. Passaremos agora à segunda (civilização/litoral x sertão/barbárie), tentando estabelecer como se articula intimamente com a primeira e com a terceira, a raça. Em torno dessas três categorias cognitivas nucleantes (admitimos, repito, a possibilidade de existência de muitas outras), organizou-se boa parte das possibilidades de expressão do e sobre o campo de significados constituído pelo sertão. Como se incluem ou se excluem as possibilidades civilizatórias no sertão? Primeiramente, o que permite ou o que proíbe a civilização no sertão? O que a inclui ou o que a exclui do interior do campo simbólico do sertão?

\section{Sertão, Litoral, Raça e Civilização na Literatura de Viagens}

Vários diacríticos são atualizados nestes discursos para incluir ou excluir a civilização do sertão ou, como dissemos acima, para caracterizar uma "civilização natural" no sertão. Trabalharemos, então, apenas com alguns deles, diretamente ligados aos objetivos deste trabalho.

Como vimos no texto de Saint-Hilaire, a exuberância da natureza sertaneja é diluidora das características mais "elevadas" dos povos. A natureza é então freqüentemente absorvente e dissipadora. Mas existem fatores outros, além desse, que incrementam a inviabilidade da civilização no sertão ou a eventualidade de uma natureza civilizada. Um desses fatores é a violência presente no sertão.

Primeiro, uma violência própria da natureza, do clima inclemente, da fauna estranha e ameaçadora, da flora rica e exuberante, por um lado, mas opressiva e sufocante, por outro. Mas existe também a violência dos homens. Spix e Martius insinuam esta influência deletéria da natureza nos "filhos do sertão":

\footnotetext{
34 "Em sendo um organizador mental do mundo, o sertão é elemento de uma estrutura de pensamento que se funda na oposição com a noção de litoral. Esta é a dualidade persistente que se desdobra em várias 'séries significativas' que se transformam segundo a história e a disposição dos atores da enunciação.[...] Somente o contexto de significação pode dar acesso aos sinônimos". VIDAL E SOUZA, Candice. Crescer para dentro. O Imaginário da Fronteira no Pensamento Social Brasileiro. Discursos Intelectuais e Políticos, Brasília, Março de 1994, mimeo.
}

PRISMAS: Dir., Pol.Pub. e Mundial., Brasília, v.3, n, 2, p 427-454, jul/dez.2006 
A 12 de julho, avistamos à nossa frente uma parte da serra de Bento Soares, e, ao anoitecer, chegamos ao arraial de formigas situado numa vargem ao pé desta serra baixa. Os habitantes deste pequeno povoado, constituído de algumas filas de cabanas baixas, todas de barro, são, como os filhos do sertão, mal afamados como brigões e por seu banditismo ${ }^{35}$

Já em Saint-Hilaire, um pouco diferente de Spix e Martius, apesar do "calor do clima" ter abrandado seus costumes e enfraquecido o natural instinto de violência, mesmo assim, tais homens "pouco realmente ganharam em civilização":

Tudo o que precede prova que os sertanejos não mais cometem grandes crimes, e que, enervando-os, o calor do clima abrandou seus costumes, pouco realmente ganharam quanto a civilização. A prostração que sucede à agitação febril não significa saúde. O povo do deserto é atualmente bom, hospitaleiro, caridoso, pacífico, mas essas virtudes são apenas o resultado de seu temperamento e deixa-se levar por ele sem esforço e como que por instinto. Estranhos às idéias elevadas e combinações generosas, quase que completamente estranhos, mesmo, ao exercício das faculdades intelectuais, os sertanejos levam uma existência animal e não saem de sua apatia senão para entregar-se às voluptuosidades mais grosseiras. ${ }^{36}$

Aqui, os atributos sociais "bom, hospitaleiro, caridoso, pacífico" permanecem vistos como determinados, em última análise, pela natureza. São, naqueles homens, nada mais do que o próprio "resultado de seu temperamento" e, por ele, o sertanejo deixa-se levar "sem esforço e como que por instinto". Como conseqüência, os sertanejos são, aos olhos de SaintHilaire, quase nada além de selvagens, tão próximos da natureza que estão fadados e reduzidos a levar "uma existência animal" e, por conta disso, "não saem de sua apatia senão para entregar-se às voluptuosidades mais grosseiras".

A incredulidade ou a ausência de religião é, também para Saint-Hilaire, diacrítico de bestialidade, só comparada à dos índios, talvez o mais "natural" ser do sertão, aliás, de resto, fortemente presente na composição étnica do elemento sertanejo.

À sombra destes abusos vi uma grosseira incredulidade insinuar-se pelo deserto; se não tomarem cuidado, ela acabará por embrutecer a homens que tem tão grande necessidade de moral e civilização e acabarão por cair em um estado pior que o dos índios. ${ }^{37}$

Note-se que "homem" aqui se diferencia de "índio", este possuindo qualidade diversa e ocupando posição diferente numa escala civilizacional previamente dada $^{38}$. Para

\footnotetext{
${ }^{35}$ Spix e Martius. Op. Cit., p. 68.

${ }^{36}$ SAINT-HILAIRE, Auguste de. Op. Cit., p. 309.

${ }^{37}$ Ibidem, p. 310.

${ }^{38}$ Falando genericamente dos viajantes, Ilka Boaventura nota que, neles, "as representações sobre o Outro nascem de um processo de comparação, classificação e ordenação dessas experiências. A imagem do outro dependeu invariavelmente de hierarquização, estando, portanto, diretamente vinculada ao referencial teórico disponível. O crivo evolucionista que irá perpassar o conjunto das representações sobre o Brasil não apenas durante o período colonial, mas também durante todo o século XIX, colocará sob suspeitas todas as pesquisas produzidas por autores estrangeiros". BOAVENTURA.LEITE, Ilka Op. Cit., p. 38/39.
}

PRISMAS: Dir., Pol.Pub. e Mundial., Brasília, v.3, n, 2, p 427-454, jul/dez.2006 
Saint-Hilaire, os "homens" são os brancos europeus (e alguns resultados das mestiçagens, consideradas inconvenientes, porém naturalmente melhores que os índios), civilizados e religiosos, isto é, educados dentro dos quadros da moralidade cristã e postos em relação assimétrica ao índio (pagão e bárbaro, filho do sertão). Entretanto, se os "homens" "não tomarem cuidado", a incredulidade, a grosseria própria do deserto e característica dos seus filhos naturais (os índios), acabará finalmente por embrutecê-los, igualando-os ou até o deixando "em um estado pior que o dos índios". Aqui, o perigo para o qual aponta SaintHilaire é o de todos virarem índios, isto é, o perigo de o sertão a todos engolir.

Nesta pequena passagem de Saint-Hilaire, articulam-se, num raciocínio essencialista explícito, algumas das principais categorias do campo de significados estabelecido como "sertão", tais como raça (branco e índio), litoral (associado ao lugar de origem do branco europeu em oposição a deserto, lugar potencialmente perigoso, berço dos índios) e civilização (conferida pela religião e a moral cristã, atributos civilizacionais entendidos como essenciais às duas primeiras categorias). Por sua vez, opõem-se a elas índios, barbarismo e sertão.

Mas, o que para Saint-Hilaire propicia ultrapassar a fronteira que separa o índio ou o sertanejo do "homem" (identificado ao branco) e que habilita àqueles almejarem alguma esperança de civilização, com certeza, é a mistura com o elemento branco. Os tipos mestiços de branco e índio (o ponto mais alto da escala de evolução civilizacional antes do branco), por piores que sejam, são ainda melhores que os índios e, não restam dúvidas, muito melhores que os negros. Mas também os mestiços foram arrastados pela força centrípeta da natureza. Esta se manifesta na ação avassaladora do calor, do clima adversário do "homem", que, por sua vez, reverbera no sertanejo produzindo ociosidade, indolência, violência ou mesmo incredulidade.

A população atual do sertão é quase toda ela composta de homens de cor.
Não havia, por ocasião de minha viagem senão dois homens brancos na
povoação de Contendas, e não vi mais do que um único durante os quatro
dias que passei na de Coração de Jesus. A indolência dos habitantes do
sertão é, talvez, maior ainda que a dos outros mineiros. Sua fisionomia
revela-lhes já a índole, e se encontra a expressão desse defeito em todos os
movimentos de seu corpo. Aliás, o calor do clima convida bastante os
homens dessa gleba a entregarem-se à ociosidade"39

Aqui, está claro, a indolência e ociosidade são favorecidas pelo calor e pela inclemência do clima; porém é a cor, é o fato de que "a população atual do sertão é quase toda ela composta de homens de cor", o fator determinante para atributos sociais tão desprezíveis.

${ }^{39}$ Ibidem, p.. 308.

PRISMAS: Dir., Pol.Pub. e Mundial., Brasília, v.3, n, 2, p 427-454, jul/dez.2006 
A prova disso é que "a expressão desse defeito", manifestada por "todos os movimentos do seu corpo", se apresenta, sobretudo, na sua "fisionomia" que, por sua parte, "revela-lhes já a índole".

Spix e Martius praticamente reproduzem os argumentos de Saint-Hilaire a respeito dos não-brancos no sertão e sua perigosa proximidade com a natureza. Para Spix e Martius, o sertanejo, isto é, o não-branco (ainda que produto da mistura com o elemento branco), é uma "criatura da natureza", a quem falta o "sentimento da delicadeza moral", a inteligência da "instrução" e um mínimo sentido "espiritual". Tais elementos humanos no sertão, entregues freqüentemente à única dimensão que lhes sobra, a dimensão da sensualidade grosseira e irrefreável ----- a única apropriada a um ser natural, não podem constituir-se em agentes civilizadores.

A natureza do sertão, portanto, tirou-lhes praticamente todas as possibilidades de uma "civilização civilizada" a inteligência ou capacidade intelectual, a moral, os costumes polidos, a delicadeza, a religião, o gosto pelo trabalho etc.. A condição de não-brancos, por si também uma determinante natural, contribuiu finalmente para caracterizá-los como portadores ou capazes de constituir, no máximo, uma "civilização natural”.

A oposição branco/não-branco, como vimos, uma categoria cognitiva nucleante, organizadora do campo simbólico do sertão, desdobra-se e interpenetra-se em outras como civilizado/não-civilizado, civilizado/natural, vazio ou deserto, utilizando e manipulando outros tantos signos - ausência de moral, indolência, violência, preguiça, incredulidade, sensualidade etc-, para compor ou caracterizar o campo de significados do sertão como um "vazio", vazio social, vazio civilizacional, que conta com uma única esperança para deixar de ser uma "civilização natural" e passar a uma "civilização civilizada": o concurso e a influência enrijecedora do homem branco.

Isto fica claro, por exemplo, na satisfação expressa por Spix e Martius quando, prontos a iniciar sua incursão à "vastidão deserta e mal afamada do sertão", encontram o que consideram um "bom agouro", um francês das belas margens do Garona, "digno" ancião que "amavelmente nos deu hospedagem".

Achamo-nos agora no sertão como denominam os mineiros a vastidão deserta, na sua linguagem usual. Consideramos de bom agouro à entrada do tão mal afamado território, o encontro com um francês das belas margens do Garona $^{40}$

\footnotetext{
${ }^{40}$ SPIX E MARTIUS, Op. Cit. , p. 65.

PRISMAS: Dir., Pol.Pub. e Mundial., Brasília, v.3, n, 2, p 427-454, jul/dez.2006
} 
Neste discurso naturalista e naturalizador de Saint-Hilaire, Spix e Martius, está presente um aspecto que é característica freqüente e própria deste tipo de narrativa: a separação de dois elementos em dois campos distintos e autônomos: primeiro, a consideração da natureza como "natureza em si” e, segundo, a percepção propriamente humana ou social dessa mesma natureza.

Em Paisagem e Memória, Schama assinala que "conquanto estejamos habituados a situar a natureza e a percepção em dois campos distintos, na verdade elas são inseparáveis. Antes de poder ser um repouso para os sentidos, a paisagem é obra da mente. Compõe-se tanto de camadas de lembranças quanto de estratos de rochas" "41, e acrescenta que "parece correto reconhecer que é nossa percepção transformadora que estabelece a diferença entre matéria bruta e paisagem" ${ }^{42}$. Com isso, quis o autor chamar a atenção para o processo mesmo de como é "construída" ou "fabricada" a paisagem. Isto é, sempre a partir de lembranças, de um esquema cultural, de um código de valores anterior ou imiscuído à percepção em si. Considera, portanto, que "Natureza", neste sentido, não pode ser algo que se apresente ao pensamento, independentemente de toda investidura simbólica, como um artifício do raciocínio. A “paisagem” é, enquanto conceito, ao contrário, reconhecida e identificada por este artifício, não escamoteadora ou disfarçadora, mas indicadora da inseparabilidade desses dois aspectos.

A própria palavra "paisagem", no idioma inglês, significa um cenário que conta, por si mesmo, uma determinada história, assinala Schama ${ }^{43}$. Da mesma forma, as "paisagens" $" 44$ do sertão, descritas por Saint-Hilaire e Spix e Martius, querem, a partir deste artifício, descrever e ao mesmo tempo contar uma história. Sugerir, por si só, pela força de sua exuberância, pelo seu poder avassalador que, insistem os autores, a tudo arrasta e absorve em seu âmbito a configuração de um domínio particular, de seres determinados pela natureza

\footnotetext{
${ }^{41}$ SCHAMA, Simon Paisagem e memória. São Paulo: Companhia das Letras, 1996, p; 17.

42 Ibidem, p. 20.

43 "Ela entrou na língua inglesa junto com herring (arenque) e bleached linen (linho alvejado), no final do século XVI, procedente da Holanda. E landschaf, como sua raiz germânica, landschaft, significa tanto uma unidade de ocupação humana uma jurisdição, na verdade quanto qualquer coisa que pudesse ser o aprazível objeto de uma pintura. Assim, certamente não foi por acaso que nos campos alagados dos países baixos, cenário de uma formidável engenharia humana, uma comunidade desenvolveu a idéia de uma landschaf, que, no inglês coloquial da época, se tornou landskip. Seus equivalentes italianos, o ambiente idílico e pastoril de riachos e colinas cobertas de dourados trigais, eram conhecidos como parerga, e constituíam os cenários auxiliares dos temas comuns da mitologia clássica e das escrituras sagradas. Nos Países Baixos, contudo, o desenho e uso da paisagem por parte do homem ------ sugerido pelos pescadores, vaqueiros, caminhantes e cavaleiros que povoam os quadros de Esaias Van de Velde, por exemplo era a própria história, espantosamente autosuficiente". Ibidem, p.. 20/21.

${ }^{44}$ Indicativo desse processo, no português, segundo Silveira Bueno, "paisagem" seria "o aspecto complexo de um lugar, a vista do país, p.rovém da linguagem dos pintores, que reproduziam cenas campestres. Fr, paysage; Ital, paesaggio.". SILVEIRA BUENO, Francisco da. Grande dicionário etimológico-prosódico da língua portuguesa. São Paulo: Saraiva, 1966. VI Vol., p. 2826.
}

PRISMAS: Dir., Pol.Pub. e Mundial., Brasília, v.3, n, 2, p 427-454, jul/dez.2006 
e de uma história própria a eles. Neste sentido, portanto, nossos autores viajantes são herdeiros de uma antiga tradição.

Desde o século XVII, desenvolveram-se manuais de desenho ou "conselhos práticos" sobre a correta maneira de elaborar uma paisagem. A "confecção" da paisagem passou a possuir, então, um esquema pré-determinado ou anterior à sua própria "fabricação". Estas paisagens, que contavam sempre uma "história", passaram, todavia, a contá-la a partir de uma "maneira correta" de se construir a paisagem. A história que contavam, por conseqüência, deveria também contar uma "história correta".

Se, portanto, esta história a ser contada deveria ser a história correta, não se poderia contar uma história qualquer, mas a história. Uma história que fosse um "corretivo moral contra os males da corte e da cidade". Schama esclarece:

Com a moda das paisagens holandesas estabelecida na Inglaterra, o artista erudito Henry Peacham incluiu em seu manual de desenho, 'Graphice', o primeiro conselho prático dirigido a seus compatriotas, sobre amaneira de elaborar uma Landskip. No entanto, para que ninguém pensasse que bastaria transpor para uma forma bidimensional os objetos de sua contemplação, Peacham tratou de desfazer possíveis equívocos publicando, no mesmo ano, o livro de emblemas 'Minerva Britannia'. Colocado ao lado de uma imagem da arcádia inglesa, o emblema 'Rura mihi et silentium' deixava claro que a vida campestre devia ser valorizada como um corretivo moral contra os males da corte e da cidade, pelas propriedades medicinais de suas plantas; pelas associações cristãs de ervas e flores ; e, sobretudo, por sua proclamação da estupenda benevolência do criador. ${ }^{45}$

O olhar objetivo de Saint-Hilaire, de Spix e Martius tinha, portanto, uma vasta tradição de "educação" e "conformação" cultural dos sentidos. As paisagens que "descrevem" não só almejam contar por si sós uma história, como contam, a partir de valores, idéias, concepções e significados previamente dados, a história, a única verdadeira, adequada e desejável de ser lida ${ }^{46}$.

Numa interessante reflexão sobre o trabalho de organização e construção artísticas da paisagem, Gombrich assevera que "mesmo para descrever o mundo visível em imagens precisamos de um sistema de Schemata bem desenvolvido"47. Schemata, para o autor, seria um esquema conceitual ou simbólico prévio à representação, que forneceria um vocabulário

\footnotetext{
${ }^{45}$ Ibidem, p.. 21.

46 'Mas, mais profundamente, a procura dos critérios 'objetivos' de identidade 'regional' ou 'étnica' não devem fazer esquecer que, na prática social, estes critérios [...] são objeto de 'representações mentais', quer dizer, de atos de percepção e de apreciação, de conhecimento e de reconhecimento em que os agentes investem os seus interesses e os seus pressupostos, e de 'representações objetais' em coisas [...] ou em atos, estratégicos interessados de manipulação simbólica que tem em vista determinar a representação mental que os outros podem ter destas propriedades e dos seus portadores”, BOURDIEU, Pierre. Op. Cit., p. 112.

${ }^{47}$ GOMBRICH, Ernst Hans. Arte e ilusão. São Paulo: Martins Fontes: 1995, p. 93.

PRISMAS: Dir., Pol.Pub. e Mundial., Brasília, v.3, n, 2, p 427-454, jul/dez.2006 
ou um quadro dentro do qual, e só a partir dele, o artista pudesse se aventurar a "copiar" a realidade.

Referindo-se também às representações pictóricas holandesas mencionadas por Schama, Gombrich assinala que:

Mesmo as pinturas de gênero holandesas, que parecem um espelho da vida em todo o seu tumulto e variedade, se revelarão como produto de um número limitado de tipos e gestos, do mesmo modo como o aparente realismo do romance picaresco ou da comédia da restauração inglesa ainda utiliza e modifica figuras estereotipadas cuja criação remonta a séculos atrás. Não há naturalismo neutro. $\mathrm{O}$ artista, não menos que o escritor, precisa ter um vocabulário antes de poder aventurar-se a uma 'cópia' da realidade. ${ }^{48}$

Para Gombrich, o artista só se deixaria atrair "por motivos que podem ser representados nos seu idioma. Ao esquadrinhar a paisagem, as vistas que podem ser ajustadas com êxito à schemata que ele aprendeu a manejar saltam aos olhos como centros de atenção. O estilo, como veículo, cria uma atitude mental que leva o artista a procurar na paisagem que o cerca elementos que seja capaz de reproduzir"49.

As representações da natureza ou a "construção da paisagem" no texto escrito obedeceriam também à mesma atitude e disposição mental. Hayden White explica que, no processo de produção do texto, o autor desenvolve um conjunto de estratégias narrativas mediante as quais um aglomerado de elementos e eventos são arranjados de modo a conferir à narrativa o poder de sugestão de que aquilo que se narra é inevitável, necessário e total. A linguagem que o historiador usaria para arranjar ou organizar esse aglomerado de elementos e eventos, isto é, para "descrever" quer a "realidade" de uma paisagem ou região, quer o desenrolar de um processo histórico, seria ditada pelo tipo de urdidura de enredo que o historiador decidisse utilizar. Neste caso, o tipo de linguagem prescreveria as formas fundamentais da história a ser contada. Dessa maneira, as formas das relações que no discurso "naturalista" pareceriam ser inerentes aos "elementos naturais dados" seriam, de outra feita, impostas e determinadas pelo historiador no momento exato de identificar e descrever.

Isto posto, os "fatos" ou os "elementos naturais", ao invés de constituírem uma história por si mesmos, integrariam uma história de certa forma já constituída “a priori”, pelo

\footnotetext{
${ }^{48}$ Ibidem, p.. 92.

${ }^{49}$ Ibidem, p.. 90.

PRISMAS: Dir., Pol.Pub. e Mundial., Brasília, v.3, n, 2, p 427-454, jul/dez.2006
} 
tipo de enredo e linguagem escolhida ${ }^{50}$. Enfim, a "descrição" dos eventos ou da paisagem já constitui, por si, de antemão, interpretações da "natureza". Nas palavras de White:

São os tipos de discursos figurativos que ditam as formas fundamentais dos dados a serem estudados. Isto significa que a forma das relações que parecerão ser inerentes aos objetos que habitam o campo na realidade foi imposta ao campo pelo investigador no próprio ato de identificar e descrever os objetos que aí descobre. Daí que os historiadores constituam os seus temas como possíveis objetos de representação narrativa por meio da própria linguagem que utilizam para descrevê-los. E, a ser esse o caso, isso significa que os diferentes tipos de interpretação histórica que temos do mesmo conjunto de eventos [...] são pouco mais que projeções dos protocolos lingüísticos utilizados por estes historiadores para prefigurar esse conjunto de eventos antes de escrever as suas narrativas. ${ }^{51}$

Enfim, tanto do ponto de vista imagístico ou pictórico, quanto do ponto de vista do artefato literário, os sertões descritos por Saint-Hilaire, Spix e Martius e outros autores estão antes determinados pelos seus "olhares", construídos a partir do patrimônio cultural referentes aos lugares de origem destes autores e dos valores próprios da época em que eles escreveram. Qualquer aproximação do homem sertanejo ou do não-branco feito a partir deles implica acionar mediações lingüísticas, simbólicas ou um quadro prévio de valores, concepções e determinado contexto histórico.

Parafraseando o que Edward Said afirmou sobre as percepções ocidentais do oriente, os sertões também não estariam "meramente lá, assim como o próprio ocidente não está lá. Devemos levar a sério a notável observação de Vico, segundo a qual os homens fazem sua própria história, e que só podem conhecer o que fizeram, e aplicá-la à geografia: como entidades geográficas e culturais para não falar das entidades históricas, os lugares, regiões e setores geográficos tais como o 'Oriente' e o 'Ocidente' são feitos pelo homem. Portanto, assim como o próprio Ocidente, o Oriente é uma idéia que tem uma história e uma tradição de pensamento, imagística e vocabulário que lhe deram realidade e presença no e para o ocidente" ${ }^{, 52}$.

\footnotetext{
${ }^{50}$ A isto Hayden White chama de "ação prefigurativa". Considera o autor que "o historiador defronta o campo histórico mais ou menos da mesma maneira que o gramático defrontaria uma nova língua, seu primeiro problema consiste em distinguir entre os elementos léxicos, gramaticais e sintáticos do campo. Só então poderá ele intentar a interpretação do que significam determinadas configurações de elementos ou transformações de suas relações. Em suma, o problema do historiador é construir um protocolo lingüístico, preenchido com as dimensões léxicas, gramaticais, sintáticas e semânticas, por meio do qual irá caracterizar o campo, e os elementos nele contidos, nos seus próprios termos (e não nos termos em que vêm rotulados nos documentos) e assim prepará-los para a explicação e representação que posteriormente oferecerá deles em sua narrativa, p.or sua vez, esse protocolo lingüístico preconceitual será em virtude de sua natureza essencialmente prefigurativa ----- caracterizável em função do modo tropológico dominante em que será vazado". WHITE, Hayden. A Meta-História: a imaginação histórica do século XIX. São Paulo: Edusp, 1992, p. 45.

${ }^{51}$ WHITE, Hayden. Trópicos do Discurso: ensaios sobre a crítica da cultura. São Paulo: Edusp, 1994, p. 112.

${ }^{52}$ SAID, Edward. Orientalismo: o oriente como invenção do ocidente. São Paulo: Companhia das Letras, 1990, p. 16 e 17.

PRISMAS: Dir., Pol.Pub. e Mundial., Brasília, v.3, n, 2, p 427-454, jul/dez.2006 
Artigo recebido em setembro de 2006

Aceito em outubro de 2006

\section{Referências}

AMADO, Janaína \& VALADARES PIMENTEL, Sidney (Orgs.). Passando dos Limites. Goiânia: UFG, 1995.

AUGEL, Moema Parente. Visitantes Estrangeiros na Bahia. São Paulo: Cultrix-Mec, 1980.

BOAVENTURA LEITE, Ilka. Antropologia da Viagem: escravos e libertos em Minas Gerais no século XIX. Belo Horizonte, UFMG, 1996.

BOURDIEU, Pierre. O Poder Simbólico. Rio de Janeiro-Lisboa: Bertrand Brasil-Difel, 1989.

CRISTÓVÃO, Fernando. A transfiguração da realidade sertaneja e sua passagem a mito: a divina comédia do sertão. In: Revista da USP:Dossiê Canudos. São Paulo, No. 20, Dezembro, Janeiro, Fevereiro 93-94, p.. 45.

FRÓES SCHETTINO, Marco Paulo. A idéia de vazio na noção de sertão. Brasília, Mimeo, 1994.

GOMBRICH, Ernst Hans. Arte e ilusão. São Paulo: Martins Fontes, 1995.

LEVI-STRAUSS, Claude. Antropologia estrutural. Rio de Janeiro: Tempo Brasileiro, 1989.

LIMA, Nísia Trindade. Um sertão chamado Brasil: intelectuais, sertanejos e imaginação social. Rio de Janeiro, Tese de doutoramento apresentada ao Instituto Universitário de Pesquisa IUPERJ, 1997.

SANTOS, Ana Flávia Moreira. O elemento indígena no sertão: considerações sobre o sertão norte-mineiro. Belo Horizonte, Mimeo, 1994.

ROSA, João Guimarães. Grande sertão veredas. Rio de Janeiro: Nova Aguilar, 1994.

SAID, Edward. Orientalismo: o oriente como invenção do ocidente. São Paulo: Cia das Letras, 1990.

SAINT-HILAIRE, Auguste de.Viagem pelas províncias do Rio de Janeiro e Minas Gerais. São Paulo:Itatiaia, 1975.

SCHAMA, Simon. Paisagem e memória. São Paulo: Cia. das Letras, 1996.

SILVEIRA BUENO, Francisco. Grande Dicionário Etimológico-Prosódico da Língua Portuguesa. São Paulo: Saraiva, 1966. 
SPIX E MARTIUS. Viagem pelo Brasil. São Paulo: Melhoramentos/Mec, 1976.

VIDAL E SOUZA, Candice. A Pátria geográfica: sertão e litoral no pensamento social brasileiro. Goiânia: UFG, 1995.

Crescer para Dentro: o imaginário da fronteira no pensamento social brasileiro, discursos intelectuais e políticos. Brasília, Mimeo, 1994.

WERNECK SODRÉ, Nelson. Oeste: ensaio sobre a grande propriedade pastoril. Rio de Janeiro: José Olímpio, 1941.

WHITE, Hayden. A meta-história:a imaginação histórica do século XIX. São Paulo: Edusp, 1992.

. Trópicos do Discurso: ensaios sobre a crítica da cultura. São Paulo: Edusp, 1994.

WOORTMANN, Klaas. Com parente não se Neguceia. In: Anuário Antropológico 87. Brasília, UnB/Tempo Brasileiro, 1990. 


\section{Resumo}

$\mathrm{O}$ presente artigo pretende compreender o processo pelo qual a invisibilidade social das pessoas negras foi construída através da categoria analítica e política de "Sertão". Esta abordagem será desenvolvida com relação ao pensamento social brasileiro dos fins do século XIX.

Palavras-chave: Sertão. Pensamento Social brasilero.
The present article aims at studying the process by which the social invisibility of the black people was constructed by means of the analytic and politic cathegory of "Sertão". This approach will be developed with reference to the Brazilian social thinking of the late XIX century.

Key Words: Sertão. Brazilian social thinking 